\title{
Distribution of Phytophthora vignae f. sp. adzukicola Races in Adzuki Bean Fields in Hokkaido, Japan
}

\author{
N. Kondo, A. Notsu, and S. Naito, Graduate School of Agriculture, Hokkaido University, Sapporo 060-8589, Japan; \\ and S. Fujita and H. Shimada, Tokachi Agricultural Experiment Station, Memuro 082-0071, Japan
}

\begin{abstract}
Kondo, N., Notsu, A., Naito, S., Fujita, S., and Shimada, H. 2004. Distribution of Phytophthora vignae f. sp. adzukicola races in adzuki bean fields in Hokkaido, Japan. Plant Dis. 88:875-877.

Information on the distribution of races of Phytophthora vignae f. sp. adzukicola in Hokkaido, Japan, is important for the management of Phytophthora stem rot of adzuki bean. In all, 107 isolates of $P$. vignae collected between 1999 and 2001 from 63 fields were evaluated for pathotype using four differentials. In this study, 26, 52, and 28 isolates were identified as races 1, 3, and 4, respectively. One isolate was nonpathogenic on the differentials. Race 4 isolates had the broadest host range and were widely distributed in the adzuki bean-producing regions, especially in central and western Hokkaido. Additional management measures for $P$. vignae are required if the cultivation area of an agronomically promising cultivar like cv. Syumari (susceptible to race 4) is to be increased.
\end{abstract}

Adzuki bean (Vigna angularis (Willd.) Ohwi \& Ohashi), which is a member of the subgenus Ceratotropis, is the second most important legume grown in Japan, after soybean. About 100,000 metric tons of adzuki bean are produced annually in Japan. Hokkaido, the northernmost island of Japan, is where about two-thirds of commercial production in Japan occurs (13). Widespread introduction of adzuki bean occurred in Hokkaido in the late 1880s, reaching 40,000 to 50,000 ha in the central and western through the eastern areas of Hokkaido during 1900 to 1935 . After the decline of production during World War II, land area of adzuki bean increased again in Hokkaido.

Beginning in the 1960s, overproduction of rice became a problem in Japan, leading to the national government establishing an act to equilibrate supply with demand for rice. Hence, during the 1970s, farmers were obliged and, in some cases, subsidized, to convert rice paddies into upland, nonflooded fields. Adzuki bean, an important cash crop in Japan, was grown widely in the converted fields in the central and western parts of Hokkaido.

Those poorly drained fields provide the moist environmental conditions that favors Phytophthora stem rot caused by Phytophthora vignae Purss f. sp. adzukicola

Corresponding author: N. Kondo

E-mail: norikon@res.agr.hokudai.ac.jp

This work was supported by a grant from the Japan Bean and Pea Foundation.

Accepted for publication 1 April 2004.

Publication no. D-2004-0607-05R

(C) 2004 The American Phytopathological Society
Tsuchiya, Yanagawa et Ogoshi (20). This disease was first reported in Hokkaido in 1967 (14) and became the main constraint in the production of adzuki beans in Hokkaido (7). Several methods currently are used to control this disease: fungicides (foliar and seed treatment) and cultural practices, such as high ridge cultivation, crop rotation, and increasing soil drainage (19). However, none of these have proven to be entirely effective alone.

Race-specific resistance is a major element in the management of Phytophthora stem rot of adzuki bean. A resistant cultivar, Kotobuki-shozu, was introduced in the 1970s. After a few years, Fusarium wilt, caused by Fusarium oxysporum f. sp. adzukicola, was identified in this cultivar (10). In addition, brown stem rot caused by Phialophora gregata f. sp. adzukicola also is a problem in adzuki bean production in this region $(8,9)$. With these disease pressures, producers hoped for the development of cultivars with resistance to multiple pathogens. The adzuki bean, Syumari, was developed with resistance to Fusarium wilt, brown stem rot, and Phytophthora stem rot (5).

The extensive surveys of the race distribution of Phytophthora vignae f. sp. adzukicola during 1977 to 1979 (20) and 1994 to 1995 (12) showed that races 1 and 3 were predominant in Hokkaido, while race 2 was present at a low frequency or not observed. Race designation tests in the latter survey used cv. Urasa-Shimane, which is one of the parents of cv. Syumari, as a resistant host to all races (1, 2, and 3). No isolates were virulent on this cultivar. However, in 1999, when Syumari first was grown in several experimental fields, Phytophthora stem rot was observed on it (15). A previous study (15) confirmed the pres- ence of a new race, designated race 4 , and determined a set of differential adzuki bean cultivars (Erimo-shozu, Kotobukishozu, Noto-shozu, and Syumari).

Presently, users are demanding cv. Syumari due to its excellent qualities (5). However, information on the race of $P$. vignae f. sp. adzukicola in Hokkaido adzuki bean fields is not sufficient for farmers to make cultivar selection decisions. The objectives of this study were to determine the distribution and frequency of races of $P$. vignae f. sp. adzukicola in commercial fields in Hokkaido adzuki bean-producing regions.

\section{MATERIALS AND METHODS}

Sample collection and isolation. In 1999 and 2001, 1- to 2-kg soil samples were collected from 146 fields in which Phytophthora stem rot had been observed in the past (Fig. 1). Fields, varying in size from 0.3 to 2 ha, were walked in a zigzag pattern, and 10 to 15 soil cores $(5 \mathrm{~cm}$ in diameter by $5 \mathrm{~cm}$ deep) were collected. Soil was air dried and passed through a 2$\mathrm{mm}$ screen. Soil was stored dry at room temperature until assays were made. Approximately $300 \mathrm{~g}$ of air-dried soil was dispensed into three 15 -cm-diameter vinyl pots planted with the adzuki bean cv. Erimo-shozu (susceptible to all races) as bait and placed in the greenhouse at 22 to $28^{\circ} \mathrm{C}$. After 7 days, when the seed had germinated, the soil was flooded for 2 days by placing a saucer under each pot. Two weeks after planting, small sections were taken from the edge of the expanding brown or water-soaked lesions on the hypocotyls of seedlings. They were surface disinfected in $1 \%$ sodium hypochloride for $1 \mathrm{~min}$, rinsed in sterile, distilled water, and placed on Difco cornmeal agar medium amended with $0.02 \mathrm{~g}$ of $75 \%$ pentachloronitrobenzene and $0.03 \mathrm{~g}$ of streptomycin sulfate. Single zoospore cultures were obtained following the method of Eye et al. (3). All isolates were cultured on V8 juice agar (6) and examined for morphological characteristics, including mycelia, oospore, and sporangia size and shape (16).

Race determination. Mycelia (1 g, fresh weight) from 2-week-old cultures of each isolate grown in pea broth at $25^{\circ} \mathrm{C}$ was homogenized (Nissei AM-5) at 5,000 rpm for $3 \mathrm{~min}$ with $100 \mathrm{ml}$ of sterilized distilled water (15). The pea broth contained the extract of frozen peas at 100 
$\mathrm{g} / \mathrm{liter}$, prepared by boiling with water for $15 \mathrm{~min}$ and filtering the extract with cheesecloth. The races were determined with the following differential adzuki bean cultivars $(15,20)$ : Erimo-shozu (universally susceptible), Kotobuki-shozu (resistant to race 1 and susceptible to the other races), Noto-shozu (resistant to races 1 and 2, and susceptible to races 3 and 4), and Syumari (susceptible to race 4 and resistant to races 1,2 , and 3). Sets of 12 seedlings of each of the differential cultivars were planted in sterilized vermiculite in $27-$ by- $42-\mathrm{cm}$ plastic trays in the greenhouse. Seedlings ( 7 to 10 days old) were washed gently with running tap water before inoculation. The

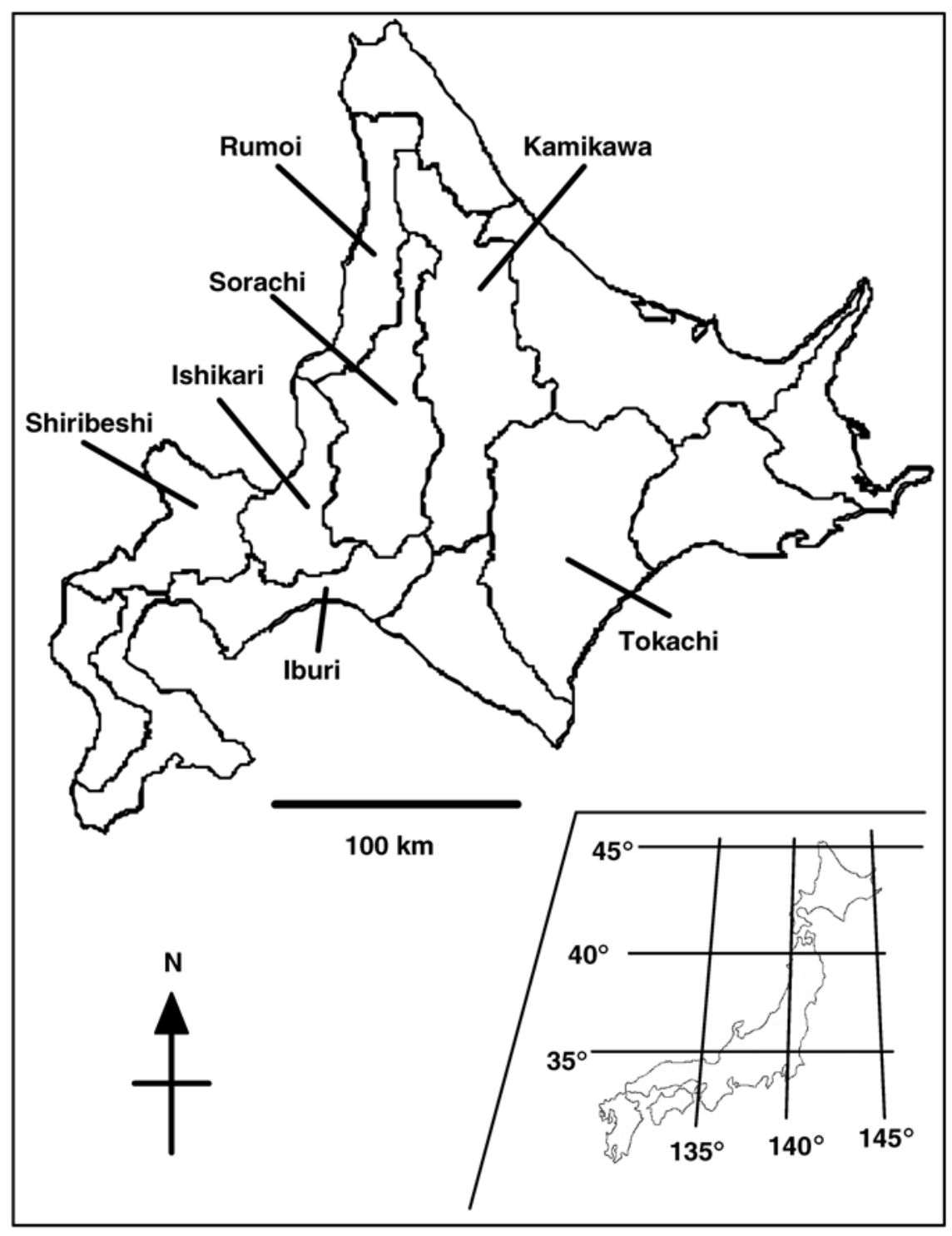

Fig. 1. Districts surveyed for the distribution of Phytophthora vignae f. sp. adzukicola races in Hokkaido, Japan.

Table 1. Location, race, and number of Phytophthora vignae f. sp. adzukicola isolates collected in Hokkaido, Japan between 1999 and 2001

\begin{tabular}{lccccc}
\hline & & \multicolumn{4}{c}{ Number of isolates } \\
\cline { 3 - 6 } District & Number of fields & Race 1 & Race 3 & Race 4 & Total \\
\hline Rumoi & 6 & 4 & 4 & 2 & 10 \\
Kamikawa & 14 & 4 & 18 & 10 & 32 \\
Sorachi & 18 & 4 & 15 & 4 & 23 \\
Shiribeshi & 6 & 3 & 2 & 5 & 10 \\
Ishikari & 6 & 0 & 5 & 3 & 11 \\
Iburi & 2 & 8 & 6 & 3 & 5 \\
Tokachi & 11 & 26 & 52 & 28 & 15 \\
Total & 63 & & 2 & & $106^{\mathrm{a}}$ \\
\hline
\end{tabular}

a One additional isolate was obtained that was considered nonpathogenic.

roots of 12 seedlings of each cultivar were soaked in the suspension of each inoculum for $12 \mathrm{~h}$, after which four seedlings per pot were transferred into a pasteurized mixed soil (vermiculite:Pot Ace, Katakura Chikkarin K. K., Tokyo; 1:1 [vol/vol] mixture) in $15-\mathrm{cm}$-diameter pots. The inoculated plants were arranged in a completely randomized design with three replications in a growth chamber at $25^{\circ} \mathrm{C}$ under $14 \mathrm{~h}$ of fluorescent light $\left(210 \mu \mathrm{E} \mathrm{cm} \mathrm{cm}^{-2} \mathrm{~s}^{-1}\right)$. Two weeks after inoculation, disease severity was evaluated using a disease severity index on a scale of 0 to 3 , where $0=$ no symptoms; 1 = a slight pigmentation or restricted lesion $(\leq 5 \mathrm{~mm})$ on the hypocotyl; 2 = an expanding brown or watersoaked lesion $(>5 \mathrm{~mm})$ on the hypocotyl, and 3 = plants are dead. Based on the reactions of adzuki bean differentials to known races of $P$. vignae f. sp. adzukicola, a differential was considered susceptible if $\geq 50 \%$ of the seedlings indicated ratings 2 or 3; otherwise, it was resistant. The tests were repeated.

\section{RESULTS AND DISCUSSION}

$P$. vignae f. sp. adzukicola was recovered from 63 of the 146 fields sampled during 1999 and 2001. As a result, 107 isolates identified as $P$. vignae f. sp. adzukicola were characterized on four adzuki bean differentials. Of the isolates evaluated, $26(24.5 \%), 52(49.1 \%)$, and 28 $(26.4 \%)$ were identified as races 1,3 , and 4 , respectively (Table 1 ). No race 2 isolate was recovered, nor was any recovered in the 1994-95 survey (12). In addition, one isolate collected from Kucchan (Shiribeshi) did not cause disease in the seedlings of any differential, including cv. Erimo-shozu, or cowpea and was classified as nonpathogenic (data not shown). Morphological similarities and $100 \%$ sequence homology in the internal transcribed spacer I region were observed between this nonpathogenic isolate and other pathogenic ones of $P$. vignae (unpublished data).

As seen in the 1994-95 survey, race 3 was predominant (12). In Tokachi district, races 1 and 3 were common, whereas only one isolate of race 4 was obtained from one field (Ikeda). Race 4 isolates were obtained from 6 of 14 fields, 4 of 6 fields, and 3 of 6 fields in Kamikawa, Shiribeshi, and Ishikari, respectively. This race is distributed widely in adzuki bean-producing regions, especially in the six districts of central and western Hokkaido, except Tokachi. Due to the cool climate conditions and volcanic ash soil, it was impossible to develop rice paddy fields in most of Tokachi district except in Ikeda. Although Phytophthora stem rot was observed at Memuro in Tokachi district soon after the first report (14), favorable conditions, such as the warm climate in summer and peat or heavy clay soils in central and western districts, might have facilitated the prolif- 
eration, survival, or diversity of the pathogen.

Because cv. Syumari has excellent processing qualities and resistance to Phialophora gregata f. sp. adzukicola race 1, Phytophthora vignae f. sp. adzukicola races 1,2 and 3, and $F$. oxysporum f. sp. adzukicola races 1, 2 and 3, introduction of this cultivar had been expected in central and western districts. With the extensive cultivation of cv. Syumari, which is susceptible to $P$. vignae race 4 , there is a distinct possibility of an increase in the frequency of race 4 . This potentially could result in devastating outbreaks of this disease within a few years unless additional control measures are instituted. In addition to a combination of fungicide treatment and cultural practices such as earthing up (a tillage practice that creates furrows for irrigation that push fresh soil against the plant stems) (unpublished data), the use of non-race-specific resistance (partial resistance) to $P$. vignae should be incorporated into adzuki bean cultivars, as it was in soybeans against $P$. sojae $(2,17,18)$.

Monitoring the race or virulence structure of the pathogen population is not only a key component in any management program using specific resistance, but it also improves our understanding of the basic forces that drive pathogen evolution. Although outcrossing within a single field population is unknown, rare outcrossing, which might produce new races in $P$. sojae $(1,4,11)$, also would enable the evolution of new, virulent isolates in $P$. vignae under natural conditions. Genetic studies and molecular analyses of $P$. vignae isolates will provide information on the mechanisms that contribute to population change in $P$. vignae.

\section{ACKNOWLEDGMENTS}

We thank the Agricultural Extension Centers of the Hokkaido Prefectural Government for sampling field soils.

\section{LITERATURE CITED}

1. Bhat, R. G., and Schmitthenner, A. F. 1993. Genetic crosses between physiologic races of Phytophthora sojae. Exp. Mycol. 17:122-129.

2. Buzzell, R. I., and Anderson, T. R. 1982. Plant loss response of soybean cultivars to Phytophthora megasperma f. sp. glycinea under field conditions. Plant Dis. 66:1146-1148.

3. Eye, L. L., Sneh, B., and Lockwood, J. L. 1978. Factors affecting zoospore production by Phytophthora megasperma var. sojae. Phytopathology 68:1766-1768.

4. Förster, H., Tyler, B. M., and Coffey, M. D. 1994. Phytophthora sojae races have arisen by clonal evolution and by rare outcrosses. Mol. Plant-Microbe Interact. 7:780-791.

5. Fujita, S., Murata, K., Shimada, H., Aoyama, S., Chiba, I., Matsukawa, I., Shirai, S., Miura, T., Ochi, H., and Kondo, N. 2002. A new adzuki bean variety 'Syumari' with soilborne diseases resistance and excellent processing quality. Bull. Hokkaido Pref. Agric. Exp. Stn. 82:31-40. (In Japanese with English summary)

6. Ishiguro, K., and Ui, T. 1981. Factors influencing the germination of Phytophthora vignae Purss oospores. Ann. Phytopathol. Soc. Jpn. 47:213-217. (In Japanese with English summary)

7. Kitazawa, K., Tsuchiya, S., Kodama, F., Kamjaipai, W., Ogoshi, A., and Yanagita, K. 1978. Phytophthora stem rot of adzuki bean (Phaseolus angularis) caused by Phytophthora vignae Purss. Ann. Phytopathol. Soc. Jpn. 44:528-531. (In Japanese with English summary)

8. Kondo, N. Fujita, S. Murata, K., and Ogoshi, A. 1998. Detection of two races of Phialophora gregata f. sp. adzukicola, the causal agent of adzuki bean brown stem rot. Plant Dis. 82:928-930.

9. Kondo, N., Kobayashi, Y., Sakuma, F., Fujita, S., and Murata, K. 2002. Regional distribution of two races of Phialophora gregata f. sp. adzukicola, the causal agent of adzuki bean brown stem rot, and their genetic diversity in Hokkaido, the northernmost island of Japan. J. Gen. Plant Pathol. 68:284-291.

10. Kondo, N., and Kodama, F. 1989. Fusarium oxysporum f. sp. adzukicola, causal agent of adzuki bean wilt, and detection of three races of the fungus. Ann. Phytopathol. Soc. Jpn. 55:451-457.

11. Layton, A. C., and Kuhn, D. N. 1990. In planta formation of heterokaryons of Phytophthora megasperma f. sp. glycinea. Phytopathology 80:602-606.

12. Makino, H., Fujita, S., Murata K., Kondo, N., and Ogoshi, A. 1997. Characteristics of Phytophthora vignae isolates collected in Hokkaido. Ann. Phytopathol. Soc. Jpn. 63:530. (Abstr. in Japanese)

13. Motomiya, G., and Ito, R. 1972. Domestic production, importation and utilization of food legumes and research organization in Japan In: Symposium on Food Legumes. Proc. Symp. Trop. Agric. Res. Trop. Agric. Res. Ser. No. 6:23-32

14. Narita, T. 1977. Diseases of adzuki bean. Pages 31-34 in: Crop Diseases in Hokkaido. Obihiro Sougo Print Inc., Obihiro, Japan.

15. Notsu, A., Kondo, N., Fujita, Murata, K., and Naito, S. 2003. New race of Phytophthora vignae f. sp. adzukicola, the causal agent of Phytophthora stem rot of the adzuki bean. J. Gen. Plant Pathol. 69:39-41.

16. Purss, G. S. 1957. Stem rot: A disease of cowpeas caused by an undescribed species of Phytophthora. Q. J. Agric. Sci. 14: 125-154.

17. Schmitthenner, A. F. 1985. Problems and progress in control of Phytophthora root rot of soybean. Plant Dis. 69:362-368.

18. Thomason, P. R., Thomas, C. A., Kenworthy, W. J., and McIntosh, M. S. 1988. Evidence of pathogen specificity in tolerance of soybean cultivars to Phytophthora rot. Crop Sci. 28:714-715.

19. Tsuchiya, S. 1982. Studies on Phytophthora stem rot and its control. Ph.D. dissertation, Hokkaido University, Sapporo, Japan.

20. Tsuchiya, S., Yanagawa, M., and Ogoshi, A. 1986. Formae speciales differentiation of Phytophthora vignae isolates from cowpea and adzuki bean. Ann. Phytopathol. Soc. Jpn. 52:577584. 